\title{
PENGEMBANGAN MEDIA PEMBELAJARAN INTERAKTIF MATA PELAJARAN IPS
}

\author{
Luthfi Fatihatul Hidayah ${ }^{*}$, Moh Farih Fahmi ${ }^{2}$ \\ ${ }^{1}$ SMP Al Kamal Blitar, ${ }^{2}$ IAIN Tulungagung \\ *E-mail: luthfi.fatiha@gmai.com
}

\begin{abstract}
Abstrak: Media pembelajaran dapat membantu dan mempermudah guru untuk menyampaikan materi pelajaran IPS, serta membantu siswa untuk memahami materi IPS yang disampaikan secara menyeluruh, sehingga proses pembelajaran lebih interaktif dan menyenangkan. Penelitian ini bertujuan untuk menghasilkan media pembelajaran berbasis Macromedia Flash Player yang layak serta menghasilakan media pembelajaran berbasis Macromedia Flash Player yang efektif digunakan dalam proses pembelajaran IPS kelas VIII. Objek yang diteliti dalam penelitian dan pengembangan ini seluruh siswa-siswi kelas VIII B di sekolah SMP Al Kamal kunir. Dengan jumlah siswa 29 anak. Metode pengeumpulan yang digunakan adalah wawancara, angket dan observasi. Hasil penelitian menunjukkan bahwa ada perbedaan yang sangat signifikan antara proses pembelajaran dengan menerapkan media pembelajaran berbasis Macromedia Flash Player dengan proses pembelajaran yang tidak menerapkan media pembelajaran berbasis Macromedia Flash Player pada mata pelajaran IPS kelas VIII I di SMP Al Kamal. Diperoleh data thitung 11,594 > 1,701 maka Ho di tolak. Jadi penggunaan media pembelajaran Macromedia Flash Player pada mata pelajaran Ilmu Pendidikan Sosial (IPS) signifikan
\end{abstract}

Kata Kunci: Pengembangan, Media Interaktif, Pembelajaran IPS.

\section{PENDAHULUAN}

Media pembelajaran merupakan salah satu faktor pendukung untuk terciptanya pembelajaran yang menyenangkan. Perkembangan media akhirakhir ini sangat bejalan dengan pesat. Munculnya media dengan penggabungan gambar dan animasi mulai di minati untuk penyampaian materi pembelajaran (Sibilana, 2016).Teknologi multimedia adalah salah satu media pembelajaran baru yang boleh digunakan untuk membantu proses pengajaran dan pembelajaran lebih berkesan.

Kegiatan pembelajaran dengan media sangat membantu dalam penyampainan materi, siswa lebih aktif dan semangat mengikuti proses pembelajaran, terutama dalam pembelajaran IPS (Ainina, 2014). Namun hal ini masih belum bisa di temukan dalam proses pembelajaran di SMP Al Kamal. Siswa lebih sering diam dan hanya sebatas mendengarkan materi yang di sampaikan, terkadang ada yang mengantuk, diam, coret-coret bahkan 
bermain alat tulis. Keadaan ini ditemukan karena pada proses pembelajaran IPS, metode yang digunakan masih sangat sederhana yakni ceramah terkadang di selingi dengan hafalan, bahkan sarana pembelajaran seperti LCD, CD dan Monitor yang disediakan juga masih jarang digunakan. Sehingga respon siswa terhadap materi yang disampaikan sangat sedikit, tak jarang siswa kurang paham dengan materi yang di sampaikan (Salam, 2017). Akibatnya siswa menganggap bahwa pelajaran IPS adalah pembelajaran yang membosankan, karena proses pembelajaran ditekankan kepada penguasaan bahan sebanyak banyaknya, sehingga penggunaan metode ceramah lebih banyak dilakukan dan dipandang lebih efektif untuk mencapai tujuan (Agustina, 2016) (Putri \& Citra, 2019).

Berdasarkan pengamatan yang dilakukan disalah satu sekolah yakni di SMP AL Kamal menunjukan data bahwa 89\% siswa/siswi kelas VIII kurang memperhatikan materi IPS bahkan tidak mendengarakan materi IPS saat proses pembelajaran berlangsung. Hal ini disebabkan karena proses pembelajaran yang dilakukan sangat kaku. Pendidik/guru masih belum bisa memanfaatkan media yang tersedia di sekolah. Pemanfaatan sarana sekolah di SMP Al KAMAL yang tidak optimal ini dikarenakan guru masih kurang lihai dalam mengoprasikan sistem pembelajaran berbasis komputer dan multimedia.

Abdul Aziz Wahab mengemukakan bahwa tujuan pengajaran IPS di sekolah tidak semata-mata untuk memberi pengetahuan dan menghapal sejumlah fakta dan informasi akan tetapi lebih dari itu. Para siswa selain diharapkan memiliki pengetahuan mereka juga dapat mengembangkan segi kehidupan dimulai dari ketrampilan akademiknya sampai pada ketrampilan sosialnya (Wahab, 2008).

Hasil pengamatan yang dilakukan menunjukkan bahwa sumber daya manusia/ pendidik memiliki permaslahan dalam bidang komputer, sehingga peneliti menemukan sebuah solusi dengan membuat media pembelajaran yang mudah untuk dioperasikan, mudah difahami dan mudah untuk disampaiakan sebagai sarana penyamapaian materi pembelajaran Ilmu Pengetahuan Sosial (IPS). Media pembelajaran ini adalah media pembelajaran berbasis multimedia dengan menggunakan aplikasi program Macromedia Falsh Palayer.

Program ini dapat dijalankan pada komputer dengan jenis apapun. Aplikasi program Macromedia Falsh Palayer adalah aplikasi yang bisa 


\section{PENGEMBANGAN MEDIA PEMBELAJARAN INTERAKTIF MATA PELAJARAN IPS}

menggabungkan antara gambar, garfik, suara, animasi dan video menjadi satu kesatuan. Hasil olah gambar dan suara dapat ditayangkan dengan LCD proyektor. Media ini hampir sejenis dengan media pembelajaran menggunakan power point, hanya saja media ini lebih lengkap dan bisa menggabungkan berbagai macam objek misalnya gambar,suara, grafik dan video menjadi satu (Sari, 2018).

Melihat permasalahan diatas peneliti akan melakukan penelitian dan pengembangan media yakni macromedia flash Payer dalam pembelajaran IPS yang sering di kenal dengan pembelajaran yang tidak menyenangkan dan membosankan, agar menjadi pembelajaran yang interaktif dan menyenangkan.

\section{METODE}

Tujuan dari pengembangan ini adalah menyempurnakan media ajar yang sudah ada sehingga tercipta sebuah produk aplikasi multimedia baru yang layak digunakan sebagai media pembelajaran. Untuk mencapai tujuan tersebut, model pengembangan yang digunakan adalah penelitian pengembangan (Research and Development) yaitu metode penelitian yang digunakan untuk menghasilkan dan menguji keefektifan suatu produk tertentu(Haryati, 2012)

Model yang akan dikembangkan adalah mengacu pada model Reseach and Development (R\&D) dari Sugiyono , langkah-langkah dalam penelitian dan pengembangan ada 10 langkah, yaitu sebagaimana berikut: (1) Potensi dan masalah, (2) Pengumpulan data, (3) Desain produk, (4) Validasi desain, (5) Revisi desain, (6) Ujicoba produk, (7) Revisi produk, (8) Ujicoba pemakaian, (9) Revisi produk, dan (10) Produksi masal (Sugiyono, 2011).

Data yang dihasilkan diperoleh dari hasil validasi dan uji coba. Valid tidaknya media pembelajaran yang dibuat akan ditentukan dari kecocokan hasil validasi empiris dengan kriteria validitas yang ditentukan. Untuk menentukan valid atau tidaknya media pembelajaran mobile learning berbasis aplikasi android yang dikembangkan akan disesuaikan dengan adobsi validiitas dari teori validitas yang digagas dan dikembangkan oleh akbar. Tabel adobsi kriteria hasil validitas sebagai berikut(Akbar, 2013). 
Tabel 1. Kriteria Validitas

\begin{tabular}{llll}
\hline No & $\begin{array}{l}\text { Kriteria } \\
\text { Validitas }\end{array}$ & Tingkat Validitas & Kelayakan \\
\hline $\mathbf{1}$ & $85,01 \%-$ & Sangat valid, atau dapat digunakan tanpa & Sangat Layak \\
& $100 \%$ & revisi & \\
\hline $\mathbf{2}$ & $70,01 \%-$ & Valid, atau dapat digunakan atau tetap ada & Layak \\
& $85 \%$ & revisi kecil & \\
\hline $\mathbf{3}$ & $50,01 \%-$ & Kurang valid, disarankan tidak digunakan & Kurang Layak \\
& $70 \%$ & karena perlu revisi besar & \\
\hline $\mathbf{4}$ & $01, \%-$ & Tidak valid atau tidak boleh digunakan & Tidak Layak \\
& $50 \%$ & & \\
\hline
\end{tabular}

\section{HASIL DAN PEMBAHASAN}

Penelitian ini telah melakukan uji coba sesuai prosedur atau tahapan penelitian dan pengembangan Borg and Gall. Berikut hasil penelitian dan pengembangan

\section{Potensi dan masalah}

Pembelajaran Ilmu pengetahuan Sosial (IPS) dengan metode pengajaran lama, menjadikan siswa malas untuk mendengarkan ketika proses pembelajaran berlangsung, bahkan siswa cenderung memilih untuk tidur diatas bangku atau bermain coret-coretan saat pembelajaran berlangsung. Kegiatan seperti ini sangat menggangu siswa lain yang ingin fokus dalam belajar. Karena hampir $78 \%$ siswa dikelas memilih bermain dari pada memperhatikan pelajaran

Permasalahan tersebut harus diselesaikan sehingga informasi yang disampaikan dapat diterima secara optimal. Sehubungan dengan masalah yang terjadi peneliti memberikan solusi berupa media pembelajaran berbasis macromedia flash untuk di terapkan dalam pembelajaran Ilmu Pengetahuan Sosial (IPS).

Media ini menggabungkan antara teks, gambar, audio dan animasi yang di tampilkan dalam LCD proyektor, dengan tampilan yang menarik sesuai dengan jenjang sekolah siswa. Siswa bisa melihat langsung contoh dan gambar materi yang disampaikan, sehingga mereka tidak hanya membayangkan penjelasan dari guru. Maka penggunaan media ini dapat mempermudah penyampaian informasi, sehingga informasi yang disampaikan oleh guru dapat diterima secara optimal oleh siswa (Rahmi et al., 2019). 


\section{PENGEMBANGAN MEDIA PEMBELAJARAN INTERAKTIF MATA PELAJARAN IPS}

Materi yang dipilih dalam penelitian dan pengembangan ini adalah Kondisi Fisik Wilayah dan Penduduk indonesia pada mata pelajaran Ilmu Pengetahuan Sosial (IPS) dengan pengkhususan sub di bidang mata pelajaran Geografi.

Pemilihan materi dengan tema Kondisi Fisik Wilayah dan Penduduk indonesia sesuai bedasarkan permasalahan yang ada di dalam kelas, serta merujuk pada semester sebelumnya bahwa materi ini cukup sukar untuk dipahami oleh siswa dan siswi di SMP Al Kamal.

Penerapan media pembelajaran berbasis macromedia flash pada tema di atas, akan memberikan gambaran dan penjelasan materi lebih detail dan menyenagkan. Materi di sampaikan dengan tampilan warna dan berbagai gambar untuk menjelaskan. Misalnya arah tiup angin moushon, jika di jelaskan dengan gambar (peta) akan lebih dimengerti dari pada hanya menjelaskan dengan ceramah saja.

\section{Pengumpulan data}

Setelah potensi dan masalah, pemilihan sekolah dan pemilihan materi telah dilaksanakan. Maka langkah selanjutnya adalah melakukan data atau perencanaan penelitian dan pengembangan produk pembelajaran berbasis macromedia flash payer. Dengan langkah-langkah sebagai berikut

a. Mengumpulkan sumber belajar yang berkenaan dengan pembelajaran Pendidikan Ilmu Pengetahuan Sosial (IPS) dengan Sub materi Kondisi fisik dan wilayah indonesia sebagai pedoman materi pada saat penelitian dan pengembangan media berbasis Macromedia flash. Sumber belajar dapat di peroleh dari Buku, LKS atau Internet.

b. Memilah dan memilih materi Kondisi fisik dan wilayah indonesia dari bererbagai sumber belajar, agar relevan dan akurat.

c. Merancang desain/layout untuk tampilan materi Pendidikan Agama Islam yang sesuai dengan perkembangan dan karakter siswa sekolah menengah Pertama(SMP/MTs)

d. Menyiapkan bahan-bahan yang diperlukan untuk pengembangan media

\section{Desain produk}

a. Halaman Depan 
Pada scene Intro terdepat judul, nama creator, logo, animasi gambar yang berkaitan dengan materi, serta tombol start, tulisan kelas VIII semester genap yang menunjukkan bahwa modul ini dipergunakan untuk kelas VIII. Intro dibuat untuk menarik minat siswa agar siswa tertarik untuk membaca modul dan mengerjakannya. Selain itu, pada intro ini terdepat judul, dan tombol - tombol yang gunanya mengarahkan kita kepada menu yang nantinya diinginkan. Diantaranya KI,KD, materi, quiz dan Author

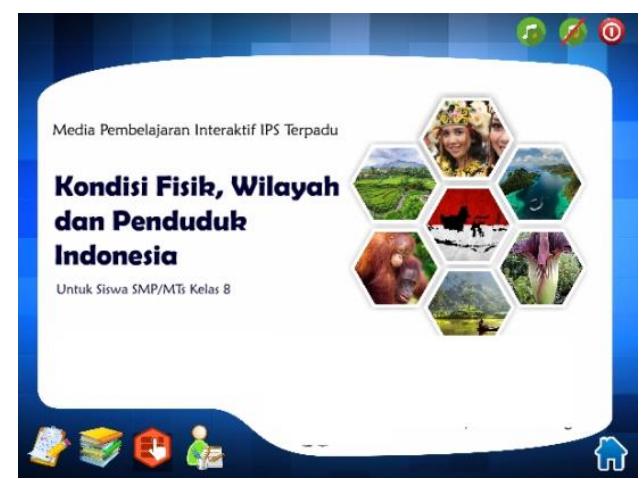

Gambar 1 Cover Media Pembelajaran berbasis Macromedia Flash

\section{b. $\mathrm{SK}, \mathrm{KD}$}

Pada screne SK,KD penulis suguhkan Standart Kompetensi dan Kompetensi dasar sesuai dengan permendikbud. Standart Kompetensi dan Kompetensi dasar dan tujuan pembelajaran bertujuan untuk menunjukkan apa yang harus siswa capai dalam pembelajaran ini.

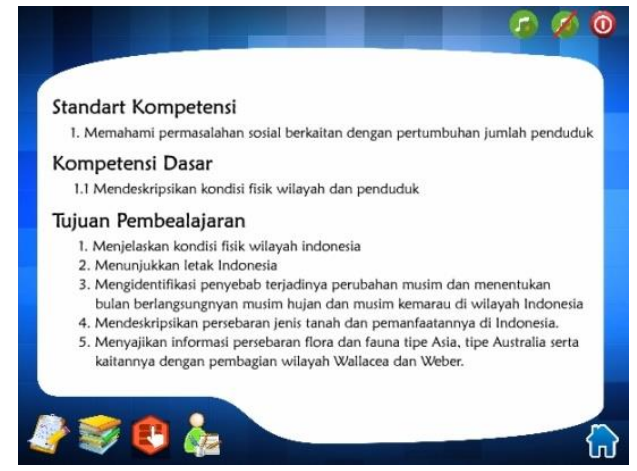

Gambar 2 Kompetensi Dasar

c. Materi

Materi pembelajaran ini didalamnya disajikan peta konsep tentang Kondisi Fisik Wilayah dan Penduduk Indonesia. Materi pertama yang akan di 


\section{PENGEMBANGAN MEDIA PEMBELAJARAN INTERAKTIF MATA PELAJARAN IPS}

pelajari yaitu Letak Indonesia. Materi yang kedua yaitu Perubahan musim di indonesia. Materi ketiga yaitu Jenis-jenis Tanah, dan materi terakhir adalah Jenis-jenis Dan Persebaran Flora Fauna di Indonesia

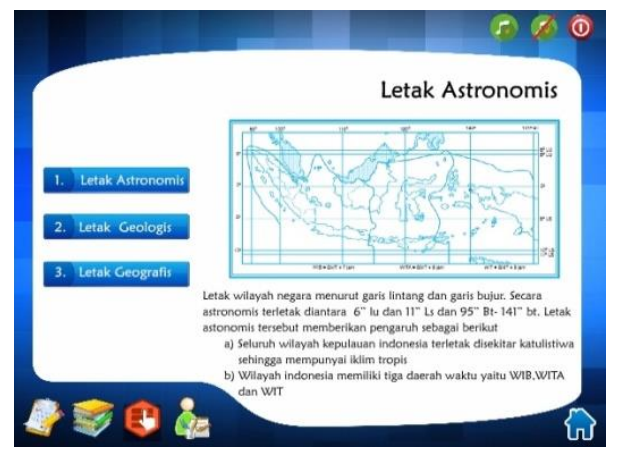

Gambar 3 Materi

d. Quiz

Pada menu quiz, siswa disajikan dengan latihan soal, siswa langsung bisa menjawabnya dan mendapaatkan nilai dari jawabannya.

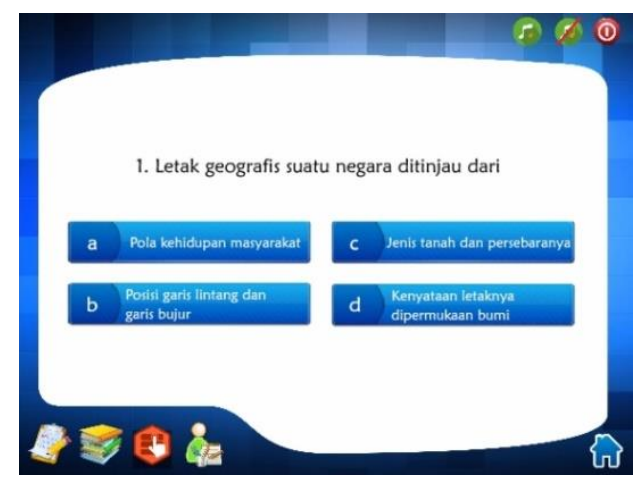

Gambar 4 Quis

\section{Validasi desain}

Sebelum diuji cobakan dilapangan diperlukan adanya validasi terhadap media yang dikembangkan. Validasi merupakan kegiatan mengumpulkan informasi data atau informasi dari para ahli dibidangnya (validator) untuk menentukan valid atau tidak valid terhadap media yang dikembangkan. Tujuan validitas adalah untuk mengetahui tingkat kelayakan media pembelajaran berbasis macromedia flash pada mata pelajaran IPS yang dikembangkan sebelum media tersebut digunakan secara umum. Hasil dari kegiatan ini 
adalah masukan untuk perbaikan media pembelajaran berbasis macromedia flash pada mata pelajaran IPS.

a. Data Hasil Validasi Ahli media

Ahli media dalam pengembangan media media pembelajaran berbasis macromedia flash pada mata pelajaran IPS di kelas VIII SMP Al Kamal Blitar. Materi yang diambil adalah kondisi fisik dan wilayah penduduk indonesia adalah orang yang kompeten dibidang desain dan teknologi pembelajaran. Pemilihan ahli media ini didasarkan pada pertimbangan bahwa yang bersangkutan memiliki kompetensi dibidangnya. Ahli media memberikan penilaian, komentar dan saran terhadap media pembelajaran ini.

Ahli media yang ditunjuk oleh peneliti untuk menilai desain media pembelajaran ini adalah Bapak Drs. H Choirul Huda,M.Si Dosen pengembangan media pembelajaran khususnya dibidang teknologi fakultas ekonomi di Universitas Kanjuruhan

Berikut akan disajikan paparan deskriptif dari hasil penelitian ahli media terhadap produk pengembangan media pembelajaran ini yang diajukan dengan metode kuisioner angket

\section{Tabel 1}

Hasil validasi ahli media terhadap pengembangan produk

\begin{tabular}{|c|c|c|c|c|}
\hline No & Aspek & & Indikator & Skor \\
\hline \multirow{4}{*}{1} & \multirow{4}{*}{ Kesederhanaan } & 1. & $\begin{array}{l}\text { Animasi dalam bahan pembelajaran IPS dengan } \\
\text { media pembelajaran berbasis macromedia flash }\end{array}$ & 4 \\
\hline & & 2. & $\begin{array}{l}\text { Animasi dalam bahan pembelajaran IPS dengan } \\
\text { media pembelajaran berbasis macromedia flash } \\
\text { mudah dimengerti }\end{array}$ & 4 \\
\hline & & 3. & $\begin{array}{l}\text { Animasi yang disajikan dalam bahan pembelajaran } \\
\text { IPS berbasis macromedia flash sesuai dengan } \\
\text { karakteristik siswa }\end{array}$ & 4 \\
\hline & & 4. & Kalimat yang digunakan mudah dimengerti & 5 \\
\hline \multirow{2}{*}{2} & \multirow{2}{*}{ Keterpaduan } & 5. & Urutan antar halaman sudah sesuai & 5 \\
\hline & & 6. & Ukuran nomor halaman sudah sesuai & 4 \\
\hline \multirow{3}{*}{3} & \multirow{3}{*}{ Keseimbangan } & 7. & Ukuran animasi dan tulisan tiap halaman sesuai & 5 \\
\hline & & 8. & Ukuran gambar pada tiap halaman sesuai & 4 \\
\hline & & 9. & Tata letak tulisan tiap halaman seimbang & 5 \\
\hline
\end{tabular}




\section{PENGEMBANGAN MEDIA PEMBELAJARAN INTERAKTIF MATA PELAJARAN IPS}

\begin{tabular}{lllll}
\hline & & 10. & Animasi yang digunakan menarik & 5 \\
& \multirow{2}{*}{ Bentuk } & 11. & Gambar menarik & 5 \\
& & 12. & Bentuk huruf mudah dibaca & 5 \\
\hline \multirow{2}{*}{5} & \multirow{2}{*}{ Warna } & 13. & Warna tiap halaman sudah sesuai & 5 \\
& & 14. & Gradasi warna sudah sesuai & 4 \\
\hline
\end{tabular}

Melihat angket yang disipkan berupa 14 aspek yang dinilai dengan skor antara 1 sampai dengan 5 katagori penilaian, maka jika 14 aspek dikaitkan dengan 5 jumlah skor idela yang diperoleh adalah 70 .

$$
\text { Prosentase }=\frac{64}{70} x 100 \%=91,1 \%
$$

Bila kita cocokan dengan tabel kelayakan yang sudah dipaparkan sebelumnya maka produk pengembangan ini berada pada kualifikasi "Sangat sesuai/Layak" dengan memiliki nilai antara 90\% - $100 \%$ itu artinya produk pengembangan ini dianggap layak untuk dipakai di lapangan meskipun hanya ada beberapa hal yang perlu diperbaiki. Adapun komentar dan saran dari ahli media sebagai berikut

1) Memperbesar ukuran animasi

Ukuran animasi yang terlihat pada media pembelajaran berbasis macromedia flash perlu di pebesar sedikit agar terlihat dari jarak yang jauh. Ukuran animasi yang besar juga dapat memberikan fokus kepada siswa/siswi karena terlihat jelas. Animasi yang terlihat jelas akan memberikan kesan yang berbeda dalam dalam tampilan media, sehingga terlihat lebih baik dan sesuai.

2) Penambahan suara

Penambahan efek suara diberikan untuk menarik perhatian siswa dalam proses pembelajaran berlagsung. Dengan efek suara yang sesuai akan menambah ketertarikan siswa terhadap materi yang ditampilkan pada media pembelajaran berbasis macromedia flash. Efek suara mendukung untuk memperjelas materi yang disampaikan.Efek Suara yang digunakan tidak perlu pada seluruh materi, melainkan pada bagian yang perlu ditonjolkan atau penting 
3) Penambahan soal-soal evaluasi

Memberikan penambahan soal-soal evaluasi pada materi yang ada dalam media pembelajaran berbasis macromedia flash. Pembuatan soal disesuaikan dengan materi yang disampaikan pada media macromedia flash. Maka jika dibutuhkan soal yang lebih peneliti disarankan menambahkan jumlah soal sebagai evaluasi dari proses belajar IPS

b. Ahli materi

Ahli materi dalam pengembangan media pembelajaran berbasis macromedia flash pada mata pelajaran IPS adalah orang yang kompeten dibidang Pendidikan Ilmu Pengetahuan Sosial. langkah ini dipilih sebagai cara untuk lebih bisa meningkatkan kualitas produk. Ahli materi memberikan penilaian, komentar dan saran terhadap media pembelajaran ini.Disini peneliti menunjuk Bapak Dr.Supriyanto.M.Pd Dosen Pendidikan Ilmu Pengetahuan Sosial Universitas Kanjuruhan Malang dan Kepala Laboraturium Pascasarjana Pendidikan IPS di Universitas kanjuruhan Malang

Berikut akan disajikan paparan deskriptif dari hasil penelitian ahli materi terhadap produk pengembangan media pembelajaran ini yang diajukan dengan metode kuisioner angket

Tabel 2

Hasil validasi ahli materi terhadap pengembangan produk

\begin{tabular}{|c|c|c|c|}
\hline No & Aspek & Indikator & Skor \\
\hline \multirow[b]{2}{*}{1} & \multirow[b]{2}{*}{ Format } & $\begin{array}{l}\text { 1. Kejelasan petunjuk penggunaan } \\
\text { 2. Kesesuaian isian pada materi }\end{array}$ & $\begin{array}{l}3 \\
4\end{array}$ \\
\hline & & $\begin{array}{l}\text { 3. Kesesuaian warna, tampilan gambar, dan tulisan } \\
\text { materi kondisi fisik dan wilayah penduduk indonesia }\end{array}$ & 5 \\
\hline \multirow{2}{*}{2} & \multirow{2}{*}{ Isi } & 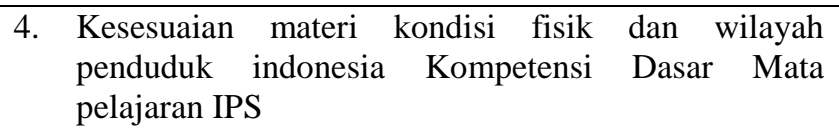 & 4 \\
\hline & & $\begin{array}{l}\text { 5. Kejelasan konsep kondisi fisik dan wilayah } \\
\text { indonesia, perubahan iklim dan persebaran flora }\end{array}$ & 4 \\
\hline
\end{tabular}




\section{PENGEMBANGAN MEDIA PEMBELAJARAN INTERAKTIF MATA PELAJARAN IPS}

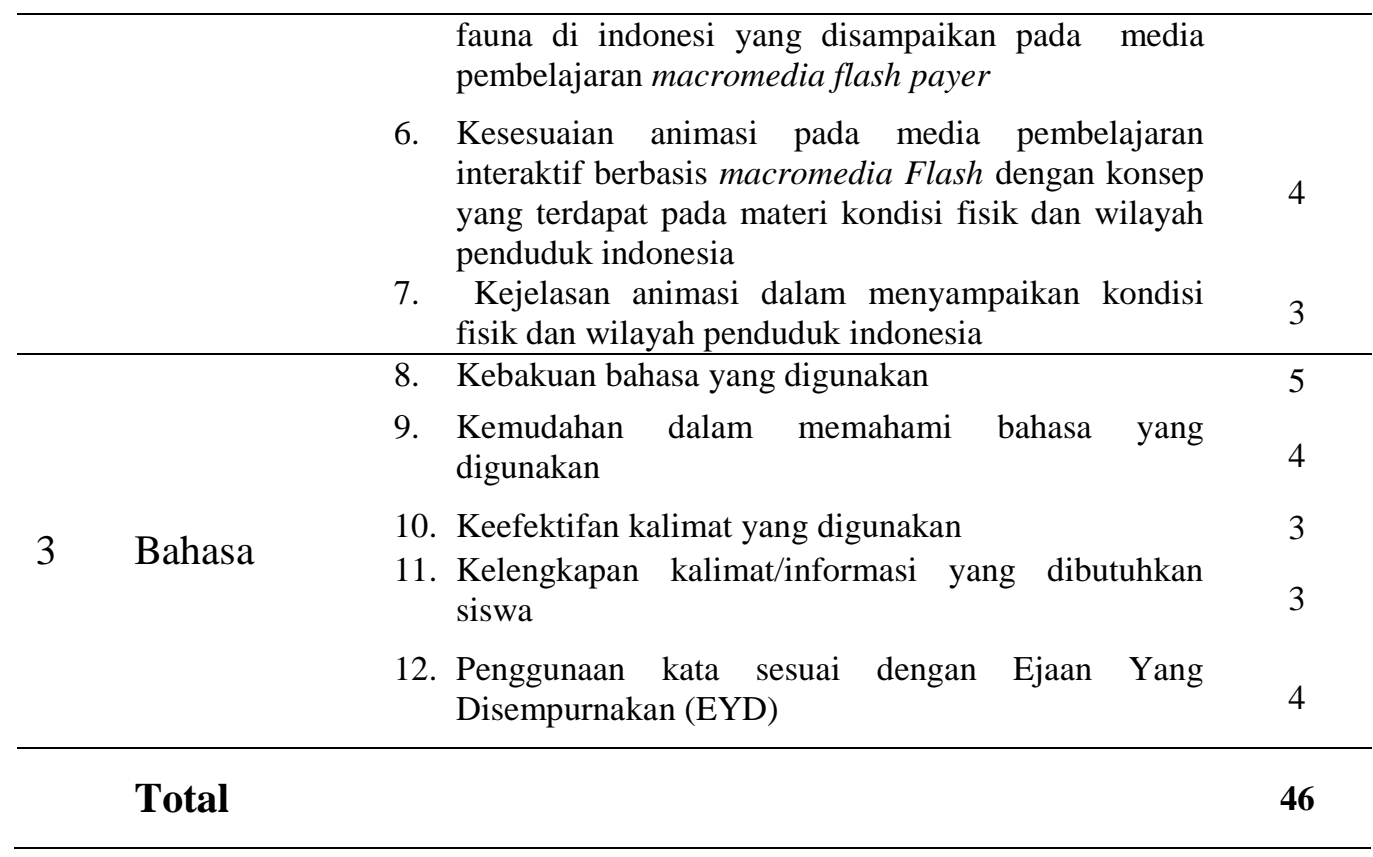

Melihat angket yang disipkan berupa 12 aspek yang dinilai dengan skor antara 1 sampai dengan 5 katagori penilaian, maka jika 12 aspek dikaitkan dengan 5 jumlah skor ideal yang diperoleh adalah 60

$$
\text { Prosentase }=\frac{46}{60} x 100 \%=76,7 \%
$$

Bila kita cocokan dengan tabel kelayakan yang sudah dipaparkan sebelumnya maka produk pengembangan ini berada pada kualifikasi "layak/sesuai "dengan memiliki nilai antara $75 \%$ - $89 \%$ itu artinya produk pengembangan ini dianggap layak untuk dipakai di lapangan. Adapun komentar dan saran dari ahli materi akan dijadikan bahan pertimbangan untuk menyempurnakan produk. Dengan penambahan perbaikan dari saran validator, media ini akan menjadi lebih baik dan layak digunakan dalam proses pembelajaran IPS. Adapun komentar dan saran dari ahli materi sebagai berikut :

1) Menambahkan petunjuk penggunaan

Kejelasan petunjuk dalam media pembelajaran sangat diperlukan. Dengan petunjuk yang jelas maka akan memudahkan pengguna untuk mengoprasikan media 
pembelajaran yang tersedia. Penambahan petunjuk yang di maksud adalah untuk mempermudah melanjutkan dari satu langkah ke langkah selanjutnya. Misalnya setelah materi 1 melanjutkan ke materi 2. Petunjuk yang di tambahkan oleh peneliti adalah berupa penamaan dari masing-masing icon dalam media bebrbasis macromedia flash, sehingga guru/ pengguna dapat memahami petunjuk yang di maksudkan.

Petunjuk yang jelas akan memudahkan guru untuk mengoperasikan media pembelajaran ini. Kemudahan pengoperasian akan membawa pada suasanan pembelajaran yang lebih kondusif dan meyeangkan. Materi yang di sampaikan bisa tersampaikan secara maksimal, karenaguru sudah memahami keseluruhan dari media sebelum proses pembelajaran berlangsung.

2) Menambahkan animasi

Animasi yang di maksudkan oleh validator adalah berupa penambahan gambar yang lebih mendukung media pembelajaran berbasi macromedia flash. Penambahan gambar disesuaikan dengan materi yang diambil akan memberikan kemudahan dalam proses pentransferan pengetahuan kepada siswa/siswi. Animasi berupa gambar pada media disesuaikan dengan kebutuhan materi dalam proses pembelajaran. Animasi bisa dirupakan juga dengan tampilan gambar yang sedikit bergerak, sehingga menarik siswa untuk melihat pada layar saat proses pembelajaran berlangsung.

3) Pembenaran bahasa

Membenahi bahasa yang sekiranya sukar di mengerti oleh siswa/siswi dalam materi media pembelajaran berbasis macromedia flash. Bahasa yang terlihat sukar dan sulit dimengerti di ganti dengan bahasa yang lebih ringan dan mudah dimengerti oleh siswa.

Bahasa yang sukar, biasanya berupa bahasa-bahasa ilmiah yang kurang dimengerti di ganti dengan bahasa yang memiliki arti yang sama tapi lebih sederhana. Dengan begitu anak lebih 


\section{PENGEMBANGAN MEDIA PEMBELAJARAN INTERAKTIF MATA PELAJARAN IPS}

mudah mengerti bahasa pada materi yang di tampilkan melalui media. Guru juga lebih mudah menjelaskan materi yang ditampilkan.

\section{c. Ahli Pembelajaran}

Ahli pembelajaran dalam pengembangan media pembelajaran IPS adalah orang yang kompeten dibidang pembelajaran Pendidikan Ilmu Pengetahuan Sosial, dalam hal ini peneliti memilih guru IPS di SMP Al Kamal Blitar. Ahli pembelajaran memberikan penilaian, komentar dan saran terhadap media pembelajaran ini. Validasi ahli pembelajaran dilakukan oleh bapak Qomarudin.M.H guru dalam bidang Pendidikan Ilmu Pengetahuan Sosial.

Berikut akan disajikan paparan deskriptif dari hasil penelitian ahli pembelajaran terhadap produk pengembangan media pembelajaran ini yang diajukan dengan metode kuisioner angket.

Tabel 3

Hasil validasi ahli pembelajaran terhadap pengembangan produk

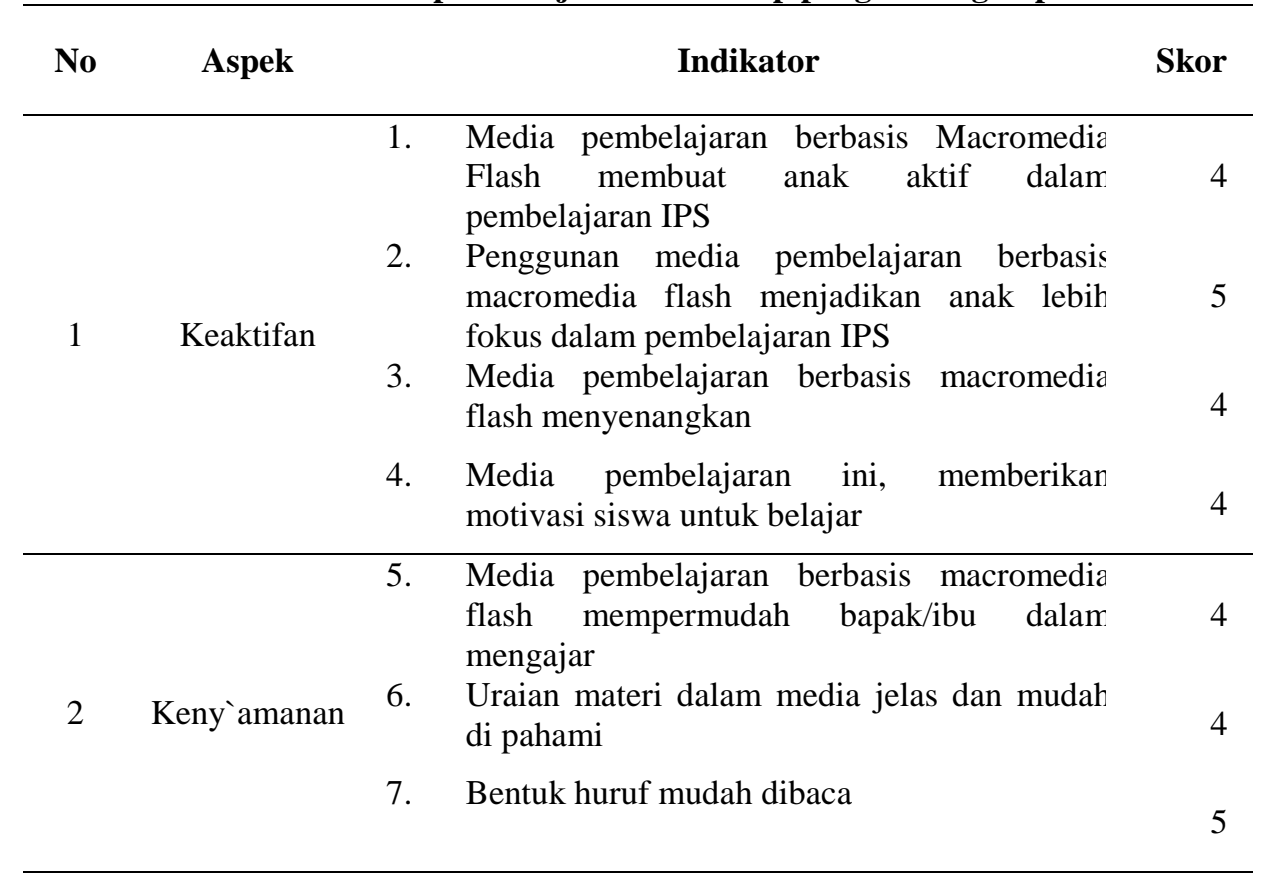




\begin{tabular}{rrlr}
\hline & 8. & $\begin{array}{l}\text { Tingkat kesesuaian antara gambar dan materi } \\
\text { dalam media pembelajaran }\end{array}$ & 4 \\
& 9. & $\begin{array}{l}\text { Media berbasis macromedia flash mudah di } \\
\text { operasikan oleh bapak/ibu guru }\end{array}$ & 4 \\
\hline 10. & $\begin{array}{l}\text { Materi yang ada dalam media ini, dijabarkan } \\
\text { dengan jelas }\end{array}$ & 4 \\
$4 \quad$ Pemahaman & 11. & $\begin{array}{l}\text { Media pembelajaran ini memenuhi kriteria } \\
\text { interaktif dan inovatif }\end{array}$ & 4 \\
& 12. & $\begin{array}{l}\text { Penggunaan animasi dan gambar } \\
\text { mempermudah siswa dalam memahami } \\
\text { materi }\end{array}$ & 5 \\
\hline Total & & & 51 \\
\hline
\end{tabular}

Melihat angket yang disipkan berupa 12 aspek yang dinilai dengan skor antara 1 sampai dengan 5 katagori penilaian, maka jika 12 aspek dikaitkan dengan 5 jumlah skor ideal yang diperoleh adalah 60

$$
\text { Prosentase }=\frac{\mathbf{5 1}}{\mathbf{6 0}} x \mathbf{1 0 0} \%=85 \%
$$

Bila kita cocokan dengan tabel kelayakan yang sudah dipaparkan sebelumnya maka produk pengembangan ini berada pada kualifikasi "Sangat sesuai/ Layak" dengan memiliki nilai antara $75 \%$ - 89 \%itu artinya produk pengembangan ini dianggap layak untuk dipakai di lapangan meskipun hanya ada beberapa hal yang perlu diperbaiki. Adapun komentar dan saran dari ahli pembelajaran sebagai berikut :

1. Soal dan Quis dibuat lebih banyak

Dari hasil validasi pembelajaran diperoleh saran untuk penambahan soal dan quis dalam media berbasis Macromedia Flash. Penambahan ini dimaksudkan untuk mengukur pemahaman siswa tentang materi yang telah disampaikan. Semakin banyak soal dan quis yang diujikan maka akan terlihat seberapa besar pemahaman siswa terhadap materi IPS yang telah disampaikan.

\section{Perbaikan desain}

Revisi didasarkan pada tanggapan, saran, dan kritik yang diperoleh dari validator, yang mana revisi ini merujuk pada bagian-bagian kesalahan yang disampaikan oleh validator. Adapun revisi tersebut adalah sebagai berikut.

1. Memperbesar ukuran animasi 


\section{PENGEMBANGAN MEDIA PEMBELAJARAN INTERAKTIF MATA PELAJARAN IPS}

2. Penambahan suara

3. Penambahan soal-soal evaluasi

4. Menambahkan petunjuk penggunaan

5. Menambahkan animasi

6. Membenahi bahasa

Perbaikan desain ini diharapkan mampu menjadikan media lebih sempirna dan sesuai dengan kebutuhan dalam proses pembelajaran.

\section{Uji coba produk}

Uji coba lapangan dilaksanakan di MTs Al Kamal Blitar selama 2 pertemuan pada kela VIII dengan jumlah siswa sebanyak 29 orang. Peneliti menggantikan guru IPS untuk mengajar di kelas VIII dengan menampilkan media pembelajaran berbasis Macromedia Flash dengan bantuan Proyektor yang terdapat dalam kelas.

Respon siswa terhadap media pembelajaran berbasis Macromedia Flash ini diperoleh dari sebaran angket yang diberikan peneliti. Berikut akan disajikan paparan deskriptif dari hasil penelitian uji lapangan terhadap produk pengembangan media pembelajaran ini yang diajukan dengan metode kuisioner angket.

Tabel 4

Hasil uji coba produk

\begin{tabular}{clcc}
\hline No & \multicolumn{1}{c}{ Indikator } & Prosentase (\%) & Katagori \\
\hline 1 & $\begin{array}{l}\text { Kemenarikan desain media pembelajaran } \\
\text { IPS berbasis Macromedia Flash }\end{array}$ & 95,17 & Sangat Layak \\
\hline 2 & Kejelasan materi untuk dipahami & 89,66 & Sangat Layak \\
\hline 3 & $\begin{array}{l}\text { Kemudahan dalam memahami contoh } \\
\text { yang diberikan }\end{array}$ & 94,48 & Sangat Layak \\
\hline 4 & $\begin{array}{l}\text { Kejelasan dalam membaca isi media } \\
\text { pembelajaran berbasis Macromedia Flash }\end{array}$ & 95,17 & Sangat Layak \\
\hline 5 & $\begin{array}{l}\text { Kejelasan bahasa yang digunakan } \\
\text { kembantu proses pemahaman materi }\end{array}$ & 94,48 & Sangat Layak \\
\hline 7 & $\begin{array}{l}\text { Kndonesia } \\
\text { Kemenarikan gambar-gambar dalam } \\
\text { menyampaikan isi materi }\end{array}$ & $\begin{array}{l}\text { Kemenarikan warna dalam media } \\
\text { pembelajaran IPS berbasis Macromedia }\end{array}$ & 95,86 \\
\hline
\end{tabular}




\begin{tabular}{clcc}
\hline \multicolumn{2}{c}{ Flash } & 94,48 & Sangat Layak \\
\hline 9 & $\begin{array}{l}\text { Kemenarikan gambar-gambar dalam } \\
\text { meningkatkan semangat belajar }\end{array}$ & Sangat Layak \\
\hline 10 & $\begin{array}{l}\text { Kemudahan mengoperasikan media } \\
\text { pembelajaran IPS berbasis Macromedia } \\
\text { Flash }\end{array}$ & 95,17 & . \\
\hline
\end{tabular}

\section{Uji coba pemakaian}

Uji ini dilakukan terhadap dua sampel yang berpasangan (paired); Sampel yang berpasangan diartikan sebagai sebuah sampel dengan subjek yang sama, namun mengalami dua perlakuan atau pengukuran yang berbeda, seperti subjek siswa/siswi kelas VIII di SMP Al Kamal Kunir akan mendapat perlakukan I (hasil belajar sebelum penggunaan media pembelajaran berbasis macromedia flash player) kemudian perlakuan II (hasil belajar setelah penggunaan media pembelajaran berbasis berbasis macromedia flash player) pada mata pelajaran Ilmu Pengetahuan Sosial (IPS) di SMP Al Kamal Kunir

\section{Tabel 5}

Paired Samples Statistics

\begin{tabular}{|rl|r|r|r|r|}
\hline & Mean & N & Std. Deviation & Std. Error Mean \\
\hline Pair 1 & setelahujimedia & 80.76 & 29 & 3.356 & .623 \\
& sebelumujimedia & 73.76 & 29 & 4.823 & .896 \\
\hline
\end{tabular}

Sumber: Data hasil Olah SPSS

Pada bagian pertama terlihat ringkasan statistik dari kedua sampel. Untuk Hasil hasil belajar siswa/siswi sebelum penggunaan media pembelajaran berbasis Macromedia Flash, siswa/siswi memperoleh nilai rata-rata 73,6 sedangkan hasil belajar setelah penggunaan media pembelajaran berbasis Macromedia Flash Player, siswa/siswi memperoleh nilai rata-rata 80,76.

Dalam hal ini, bisa juga dinyatakan bahwa terdapat perbedaan Mean Sebesar 7,0 (lihat output SPSS). Angka ini berasal dari: hasil belajar sebelum menggunakan media pembelajaran berbasis Macromedia Flash Player sesudah menggunakan media pembelajaran berbasis Macromedia Flash Player Atau 80,76 - 73,76 = 7,0. Selisih yang cukup besar menunjukkan bahwa adanya penigkatan sebesar 7,0 dari rata-rata sebelum menggunakan media berbasis Macromedia Flash Player. 


\section{PENGEMBANGAN MEDIA PEMBELAJARAN INTERAKTIF MATA PELAJARAN IPS}

\section{Tabel 6 Data hasil Olah SPSS}

Paired Samples Test

\begin{tabular}{|c|c|c|c|c|c|c|c|c|}
\hline & \multicolumn{5}{|c|}{ Paired Differences } & \multirow[b]{3}{*}{$\mathrm{t}$} & \multirow[b]{3}{*}{$\mathrm{df}$} & \multirow{3}{*}{$\begin{array}{l}\text { Sig. (2- } \\
\text { tailed) }\end{array}$} \\
\hline & \multirow[b]{2}{*}{ Mean } & \multirow{2}{*}{$\begin{array}{c}\text { Std. } \\
\text { Deviation }\end{array}$} & \multirow{2}{*}{$\begin{array}{l}\text { Std. Error } \\
\text { Mean }\end{array}$} & \multicolumn{2}{|c|}{$\begin{array}{l}\text { 95\% Confidence } \\
\text { Interval of the } \\
\text { Difference }\end{array}$} & & & \\
\hline & & & & Lower & Upper & & & \\
\hline $\begin{array}{ll}\text { Pair } & \text { setelahujimedia - } \\
1 & \text { sebelumujimedia }\end{array}$ & 7.000 & 3.251 & .604 & 5.763 & 8.237 & 11.594 & 28 & .000 \\
\hline
\end{tabular}

Pada bagian kedua dari tabel hasil uji SPSS. Maka dapat dilihat dari distribusi data yang ada pada kolom $t$

Berdasarkan perbandingan $\mathrm{t}$ hitung dengan $\mathrm{t}$ tabel:

1. Jika Statistik Hitung (angka t output) > Statistik Tabel (tabel t), maka Ho ditolak.

2. Jika Statistik Hitung (angka t output) < Statistik Tabel (tabel t), maka Ho diterima.

T hitung dari output adalah 11,594

Untuk statistik tabel bisa dicari pada tabel t, dengan cara:

1. Tingkat signifikansi $(\alpha)$ adalah $10 \%$ untuk uji DUA SISI sehingga masing-masing sisi menjadi $5 \%$.

2. df (degree of freedom) atau derajat kebebasan dicari dengan rumus

jumlah data -1 . Maka jumlah data $29-1=28$.

maka diperoleh $\mathrm{t}$ tabel adalah 1,701.

Sehingga di peroleh data t hitung 11,594 > 1,701 maka Ho di tolak. Jadi penggunaan media pembelajaran Macromedia Flash Player pada mata pelajaran Ilmu Pendidikan Sosial (IPS) signifikan. Yaitu rata-rata nilai Ilmu Pendidikan Sosial (IPS) sebelum dan sesudah penggunaan media Macromedia Flash Player adalah memang berbeda secara nyata (mengalami peningkatan). Dapat dilihat pula dalam tabel bahwa taraf signifikansi adalah $0,000 \leq 0,05$ maka dinyatakan terdapat perbedaan hasil belajar yang signifikan. Sehingga diperoleh kesimpulan dari data bahwa penggunan media pembelajaran berbasis Macromedia Flash Player efektif dalam meningkatkan hasil belajar 
siswa kelas VIII di SMP Al Kamal pada mata pelajaran Ilmu Pendidikan Sosial (IPS).

Maka dapat di ambil kesimpulan dari pengujian data melalui Uji T secara berpasangan degan taraf kebenaran Uji mencapai 95\%, bahwa penggunaan media pembelajaran berbaisis Macromedia Flash Player pada mata pelajaran Ilmu Pendidikan Sosial (IPS). dengan materi Kondisi fisik dan wilayah indosesia "layak" digunakan dalam proses pembelajaran Ilmu Pendidikan Sosial (IPS). Media ini bisa menjadi solusi bagi pembelajaran Ilmu Pendidikan Sosial (IPS).dengan memaksimalkan media pembelajaran yang selalu tersedia di sekolah yakni LCD Proyektor dan Lab. Komputer. Media ini memiliki manfaat yang baik jika digunakan secara optimal oleh guru dalam proses pembelajaran, sehingga pembelajaran Ilmu Pendidikan Sosial (IPS) lebih interaktif dan menyenangkan.(Ardinastiti, 2016)

\section{SIMPULAN}

Produk yang dihasilkan dalam penelitian pengembangan ini adalah media pembelajaran berbasis macromedia flash player materi Kondisi fisik dan wilayah indosesia pembelajaran Ilmu Pendidikan Sosial (IPS). Media pembelajaran ini sebagai aplikasi multimedia pembelajaran interaktif dan atraktif yang dapat digunakan untuk keperluan mengajar ataupun pembelajaran mandiri.

Analisis data yang telah dilakukan memperoleh hasil $91.1 \%$ dari ahli media, $76.7 \%$ dari ahli materi, 85,5\% dari ahli pembelajaran, $94.4 \%$ dari uji coba lapangan. Dari hasil analisis tersebut diambil nilai rata-rata sebesar $86,8 \%$. Berdasarkan hasil analisis data keseluruhan, diambil kesimpulan dari penelitian ini yaitu pengembangan multimedia untuk pembelajaran IPS telah layak sebagai media pembelajaran mandiri.

\section{REFERENSI}

Agustina, C. W. (2016). Problematika pembelajaran IPS bagi siswa SMP Negeri 2 Nguling Pasuruan. Universitas Islam Negeri Maulana Malik Ibrahim.

Ainina, I. A. (2014). Pemanfaatan media audio visual sebagai sumber pembelajaran sejarah. Indonesian Journal of History Education, 3(1). 


\section{PENGEMBANGAN MEDIA PEMBELAJARAN INTERAKTIF MATA PELAJARAN IPS}

Akbar, S. (2013). Instrumen perangkat pembelajaran. Bandung: PT Remaja Rosdakarya.

Ardinastiti, N. (2016). Pengembangan Media Pembelajaran Ips Berbasis Macromedia Flash Materi Hidrosfer Menggunakan Model Pembelajaran Kooperatif Tipe Numbered Heads Together Kelas Vii Smp N 1 Secang Kabupaten Magelang. Edu Geography, 4(1).

Haryati, S. (2012). Research and Development (R\&D) sebagai salah satu model penelitian dalam bidang pendidikan. Majalah Ilmiah Dinamika, $37(1), 15$.

Putri, S. D., \& Citra, D. E. (2019). Problematika guru dalam menggunakan media pembelajaran pada mata pelajaran IPS di madrasah ibtidaiyah Darussalam kota Bengkulu. Indonesian Journal of Social Science Education (IJSSE), 1(1), 49-55.

Rahmi, M. S. M., Budiman, M. A., \& Widyaningrum, A. (2019). Pengembangan media pembelajaran interaktif macromedia flash 8 pada pembelajaran tematik tema pengalamanku. International Journal of Elementary Education, 3(2), 178-185.

Salam, R. (2017). Model pembelajaran inkuiri sosial dalam pembelajaran IPS. Harmony, 2(1), 7-12.

Sari, N. R. (2018). Animation Media to Improve Student Learning Results. Jurnal Tadris Matematika, 1(2), 145-156.

Sibilana, A. R. (2016). Pengembangan media pembelajaran berbasis android mata pelajaran pendidikan agama Islam untuk kelas XI di SMA Negeri 2 Malang. Universitas Islam Negeri Maulana Malik Ibrahim.

Sugiyono, P. (2011). Metodologi penelitian kuantitatif kualitatif dan R\&D. Alpabeta, Bandung.

Wahab, A. A. (2008). Metode dan model-model mengajar: Ilmu Pengetahuan Sosial (IPS). Alfabeta. 